\title{
Impact of future warming on winter chilling in Australia
}

\author{
Rebecca Darbyshire $^{1 *}$, Leanne Webb ${ }^{1,2}$, Ian Goodwin $^{3}$, E.W.R. Barlow ${ }^{1}$ \\ ${ }^{1}$ Melbourne School of Land and Environment, University of Melbourne, Victoria, Australia \\ ${ }^{2}$ CSIRO Marine and Atmospheric Research, Victoria, Australia \\ ${ }^{3}$ Victorian Department of Primary Industries, Tatura, Australia \\ *corresponding author: r.darbyshire@student.unimelb.edu.au
}

Ph: +61383449317

Fax: +61393494218

\begin{abstract}
Increases in temperature as a result of anthropogenically generated greenhouse gas (GHG) emissions are likely to impact key aspects of horticultural production. The potential effect of higher temperatures on fruit and nut trees' ability to break winter dormancy, which requires exposure to winter chilling temperatures, was considered. Three chill models (the $0-7.2^{\circ} \mathrm{C}$, Modified Utah and Dynamic models) were used to investigate changes in chill accumulation at 13 sites across Australia according to localised temperature change related to 1,2 and $3{ }^{\circ} \mathrm{C}$ increases in global average temperatures. This methodology avoids reliance on outcomes of future GHG emission pathways, which vary and are likely to change. Regional impacts and rates of decline in chilling differ among the chill models, with the $0-7.2^{\circ} \mathrm{C}$ model indicating the greatest reduction and the Dynamic model the slowest rate of decline. Elevated and high latitude eastern Australian sites were the least affected while the three more maritime, less elevated Western Australian locations were shown to bear the greatest impact from future warming.
\end{abstract}

Key words climate change, vernalisation, fruit, nut 


\section{Introduction}

Climate plays a fundamental role in the successful production of commercial scale fruit and nut products. Winter dormancy is one key aspect of the annual cycle of deciduous fruit and nut trees along with the subsequent breaking of the dormant state. This state is maintained through the winter period each year to protect against damaging cold temperatures (Saure 1985). To be released from dormancy trees require exposure to a predetermined quantity of cold temperatures in a process known as winter chilling or vernalisation. Insufficient chilling can lead to sporadic and light bud-break, poor fruit development, small fruit size and uneven ripening times (Oukabli et al. 2003; Petri and Leite 2004; Saure 1985; Voller 1986). Expected future increases to temperature as a result of anthropogenically induced climate change may impact the vernalisation process leading to these adverse effects on production.

While the chilling process is not fully understood (Dennis 1994) the physiological response is often estimated by temperature based models (e.g. Cesaraccio et al. 2004; Fishman et al. 1987; Linsley-Noakes et al. 1994; Linvill 1990; Richardson et al. 1974; Shaltout and Unrath 1983; Weinberger 1950). Of the available models, the following are commonly used by researchers and growers; the 0-7.2 ${ }^{\circ} \mathrm{C}$ (Bennet 1949; Weinberger 1950), Utah (Richardson et al. 1974) and Modified Utah (Linvill 1990), and the Dynamic (Erez et al. 1990; Fishman et al. 1987) models. All these models, although they contain differing levels of complexity, accumulate chill according to hourly temperature exposure and, once a threshold amount of chill has been amassed, define chilling as satisfied. Different species, and varieties within species, require different amounts of chill to break dormancy. Varietal chill requirements, or thresholds, have been defined according to different chill models resulting in chill thresholds reported in different units (e.g. Table 1).

Table 1 Examples of some reported chill requirements according to different models for various fruit and nut varieties

\begin{tabular}{l|r|r|r}
\hline Variety & $\begin{array}{r}\text { Dynamic model } \\
\text { (chill portions) }\end{array}$ & $\begin{array}{r}\text { Utah model } \\
\text { (chill units) }\end{array}$ & $\begin{array}{r}\mathbf{0 - 7 . 2}{ }^{\circ} \mathbf{C} \text { model } \\
\text { (chill hours) }\end{array}$ \\
\hline Sirora pistachio & $59^{\mathrm{a}}$ & & \\
\hline Pistachio & & & $800-1000^{\mathrm{b}}$ \\
\hline Granny Smith apple & & $1040^{\mathrm{c}}$ & \\
\hline Golden Delicious apple & & $1277^{\mathrm{c}}$ & \\
\hline Starking Delicious apple & & $1234^{\mathrm{d}} ; 1208^{\mathrm{e}}$ & \\
\hline Bartlett pear & & $1210^{\mathrm{d}}$ & \\
\hline European pear & & & $600-1500^{\mathrm{b}}$ \\
\hline
\end{tabular}




\begin{tabular}{l|r|r|r}
\hline Rachele almond & & $376^{\mathrm{f}}$ & \\
\hline Scharsch Franquette walnut & $70^{\mathrm{g}}$ & & $700^{7}$ \\
\hline Orange Red apricot & $69.1^{\mathrm{h}}$ & $1266^{\mathrm{h}}$ & $739.3^{\mathrm{h}}$ \\
\hline Desmayo Largueta almond & $28^{\mathrm{i}}$ & $220^{\mathrm{i}} ; 428^{\mathrm{f}}$ & \\
\hline Brooks sweet cherry & & $556^{\mathrm{j}}$ & $36.7^{\mathrm{j}}$ \\
\hline
\end{tabular}

a Zhang and Taylor (2011)

${ }^{\mathrm{b}}$ Baldocchi and Wong (2008)

${ }^{c}$ Ghariani and Stebbins (1994)

d Ashcroft et al. (1977)

${ }^{\mathrm{e}}$ Mankotia et al. (2004)

${ }^{\mathrm{f}}$ Alonso et al. (2005)

${ }^{\mathrm{g}}$ Luedeling et al. (2009b)

${ }^{\mathrm{h}}$ Ruiz et al. (2007)

${ }^{\mathrm{i}}$ Ramírez et al. (2010)

${ }^{\mathrm{j}}$ Alburquerque et al. (2008)

Few studies have quantitatively investigated projected impacts of increased temperatures on chill accumulation, although many discuss potential negative outcomes (Darbyshire et al. 2011; Harrington et al. 2010; Legave et al. 2008; Wand et al. 2008). Hennessy and ClaytonGreene (1995) conducted one of the first investigations into chill accumulation under climate warming conditions. Their study was for Australia and used the Modified Utah model. They implemented two methods to investigate future chill conditions, a sensitivity approach as well as a range of scenarios for the year 2030 . The sensitivity study involved adding 1,2 and $3^{\circ} \mathrm{C}$ to historical temperature records, meaning a constant temperature increase was applied across all locations. Comparison between sites using this method was not possible, as the rate of warming is likely to differ between regions. Additionally, uniform minimum and maximum temperatures increases were applied, this is also unlikely to eventuate. To allow investigation into site differences they also considered scenarios for 2030 using five climate models and two emission scenarios, however these projection data was produced in 1992 and are now dated.

Recently, Luedeling et al. (2011a) conducted a global analysis of projected changes to chill accumulation according to the Dynamic model only. This model has been shown to equal or out-perform other chill models (Alburquerque et al. 2008; Campoy et al. 2011a; Erez et al. 1990; Luedeling et al. 2009b; Perez et al. 2008; Ruiz et al. 2007; Viti et al. 2010), however the results may have limited application as few varietal chill thresholds have been measured in chill portions.

Luedeling and Brown (2010) compared the output of the $0-7.2^{\circ} \mathrm{C}$, Utah and Dynamic models globally and verified that conversion factors between the chill models are regionally dependent and therefore inconsistent. Consequently, thresholds determined for varieties using 
one chill model cannot be interpreted using output from a different chill model. Some authors have concurrently investigated chill using two or more chill models (Alburquerque et al. 2008; Luedeling et al. 2011b; Luedeling et al. 2009b; Luedeling et al. 2009d; Ruiz et al. 2007; Sunley et al. 2006; Viti et al. 2010) but conversion factors between the models were conflicting. Here, three common chill models are assessed for Australian conditions, allowing investigation into chill model sensitivity to warming, consideration of projected chill accumulation measured in different units (e.g. Table 1) and comparison to other studies. Growing support for the Dynamic model and previous research highlighting the higher sensitivities of alternate chill models to warming (Luedeling et al. 2009a) indicate that results from the Dynamic model will be most applicable.

Methodology regarding interpretation of climate projection data is a major consideration in this study. Appropriate representation of Atmosphere-Ocean General Circulation Model (AOGCM) uncertainty is important for projection analyses as models can differ greatly in output (Jun et al. 2008; Watterson 2011). Emission scenarios (Nakicenovic and Swart 2000) are intentionally excluded from the analysis. This is because the IPCC's Special Report on Emission Scenarios (SRES) greenhouse gas (GHG) emission scenario storylines may not eventuate, especially if GHG production continues unabated or if mitigation policies are implemented (e.g Meinshausen et al. 2009). To improve the applicability of the results the SRES pathways are used for interpretation of results rather than embedded in the methodology.

In this study chill projections for 13 sites across Australia using three chilling models were calculated. Six AOGCMs were selected, cross-validated against existing model skill assessments (Suppiah et al. 2007; Watterson 2011), to ensure the maximum range of likely outcomes were included in the results. Temperature projections were created using localised monthly minimum and maximum temperature perturbations relating to 1,2 and $3^{\circ} \mathrm{C}$ global average temperature increases. Thus, results are comparable across locations and are independent of GHG emission projection uncertainty.

\section{Methods}

Future chill conditions were evaluated at 13 perennial horticultural production locations in Australia (Figure 1 and Table 2) as used by Darbyshire et al. (2011) for historical chilling analysis. 


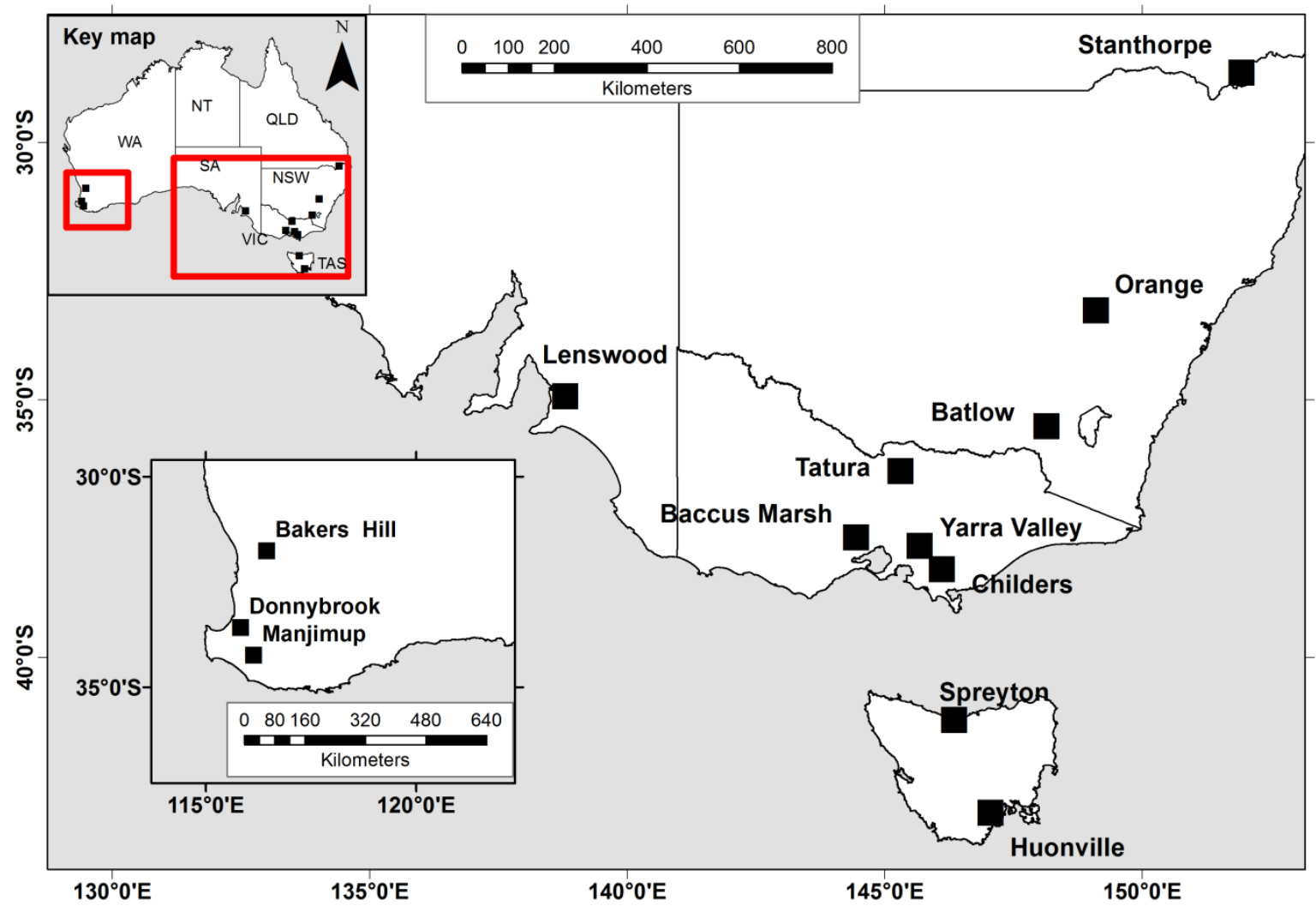

Figure 1 The 13 sites used for chill analysis for the Australian states Western Australia (WA), South Australia (SA), Queensland (QLD), New South Wales (NSW), Victoria (VIC) and Tasmania (TAS) (from Darbyshire et al. 2011).

Table 2 Geographical and climate aspects of the study sites. Elevation is measured in meters above sea level. Mean winter temperature range is the absolute mean (June, July, August) temperature range for the years 1911-2009.

\begin{tabular}{llllrr}
\hline Location & State & Latitude & Longitude & Elevation $(\mathbf{m})$ & $\begin{array}{r}\text { Mean winter } \\
\text { temperature range }\left({ }^{\circ} \mathbf{C}\right)\end{array}$ \\
\hline Batlow & NSW & -35.52 & 148.14 & 787 & $3.8-6.2$ \\
Orange & NSW & -33.27 & 149.10 & 865 & $4.7-7.9$ \\
Stanthorpe & QLD & -28.66 & 151.93 & 801 & $7.6-10.3$ \\
Lenswood & SA & -34.94 & 138.79 & 430 & $7.6-9.9$ \\
Huonville & TAS & -43.03 & 147.05 & 7 & $6.7-8.8$ \\
Spreyton & TAS & -41.22 & 146.35 & 16 & $7.6-9.8$ \\
Tatura & VIC & -36.39 & 145.31 & 112 & $7.8-9.9$ \\
Yarra Valley & VIC & -37.84 & 145.68 & 182 & $7.4-9.2$ \\
Childers & VIC & -38.30 & 146.11 & 364 & $7.2-8.9$ \\
Bacchus Marsh & VIC & -37.68 & 144.44 & 104 & $8.5-10.3$ \\
Manjimup & WA & -34.24 & 116.14 & 287 & $9.6-12.4$ \\
Donnybrook & WA & -33.58 & 115.83 & 67 & $10.1-12.9$ \\
Bakers Hill & WA & -31.77 & 116.45 & 301 & $10.0-12.8$ \\
\hline
\end{tabular}

\subsection{Climate data}

Historical daily minimum and maximum data from $1911-2009$ were sourced from $0.05^{\circ}$ by $0.05^{\circ}$ grids (Jones et al. 2009). This dataset was used by Darbyshire et al. (2011) to 
investigate historical chilling conditions in Australia as quality historical in situ meteorological data are not available at the major production areas. Climate projection output from 21 AOGCMs were provided by the Queensland Climate Change Centre of Excellence (QCCCE). The projection data were provided as localised monthly minimum and maximum temperature perturbations per $1^{\circ} \mathrm{C}$ global temperature increase from $1975-2004$ baseline. The pattern scaling methodology used to produce future climates, developed by the Commonwealth Scientific and Industrial Research Organisation (CSIRO), is described in Page and Jones (2001) and Ricketts and Page (2007). Where climate variables for some AOGCMs were not available from CSIRO, they were in-filled by QCCCE using regression methods.

\subsection{Chill models}

The 0-7. ${ }^{\circ} \mathrm{C}$ model (Bennett 1949; Weinberger 1950) is a simple step-function which records one chill hour for every hour that temperature is within the $0-7.2{ }^{\circ} \mathrm{C}$ interval and nil chill hours otherwise. The Modified Utah model (Linvill 1990) builds on the simplicity of the 0$7.2^{\circ} \mathrm{C}$ model. It incorporates an optimum chilling temperature, which is assigned one chill unit, with temperatures either side of the optimum declining in ability to contribute to the chilling process. This model additionally accounts for the negation effect of high temperatures on chilling, with temperatures over $14^{\circ} \mathrm{C}$ reversing previously accumulated chill, an aspect lacking in the $0-7.2^{\circ} \mathrm{C}$ model. These two models are time independent, meaning the effectiveness of chilling temperatures are constant across the chill period. Independence from time using the Modified Utah model means chill accumulated early in winter can be negated by late season warming.

The Dynamic model (Erez et al. 1990; Fishman et al. 1987) accumulates chill using a nonstatic approach. Cold temperatures initially contribute to the creation of an intermediate product. This product can then be destroyed by subsequent high temperatures. However, once a threshold amount of the intermediate product is amassed it is irreversibly banked as a chill portion. This model incorporates the aspects of the Modified Utah model, optimum chill temperatures and negation influences of high temperatures, although this aspect is time dependent. It further accounts for the enhancing effects of moderate temperatures on chilling. Mathematical descriptions of all three chill models are contained in Darbyshire et al. (2011). 
Luedeling et al. (2009c) developed a simple yet effective chill statistic in their assessment of future chill conditions in California. They found the $10^{\text {th }}$ percentile of accumulated chill from typical weather distributions, calculated from calibrated synthetically generated data, and classified this value as 'safe winter chill'. It represents a minimum threshold amount of chill that can be reliably expected in most years $(90 \%)$. As stated by the authors, this variable is likely to be more useful than mean chill as it indicates the minimum likely amount of chill expected rather than that expected in an average year. Luedeling et al. (2011) also used this approach to analyse future global chilling conditions. Similarly to Luedeling et al. (2009c) and Luedeling et al. (2011) results will be calculated using safe winter chill.

\subsection{Atmosphere-Ocean General Circulation Model (AOGCM) selection}

A selection of AOGCMs was made from the 21 available, whereby appropriate representation of the range of model responses was the main criteria for selection, with the benefit of reducing possible confusion resulting from presenting too much redundant information (Smith and Chandler 2010). This method described in Clarke et al. (2011), seeks to categorise and then rank AOGCM output for climate variables of interest over defined regions in Australia. Three AOGCMs (GISS-AOM, GISS-ER and GISS-EH) were not included in the model appraisal as they have been found to perform poorly in the Australian region (Smith and Chandler 2010; Suppiah et al. 2007; van Oldenborgh et al. 2005). The remaining 18 AOGCMs were assessed. Selection was performed through initially categorising the models into 'slightly warmer' $\left(<0.5^{\circ} \mathrm{C}\right)$, 'warmer' $\left(0.5-1.0^{\circ} \mathrm{C}\right)$ and 'hotter' $\left(>1.0^{\circ} \mathrm{C}\right)$ groupings, for each AOGCM region, following Clarke et al. (2011). Through this approach the relative likelihood of the category can be evaluated through calculating the percentage of all models that fall into each category. Then for each AOGCM area the absolute hottest and coolest models were identified and included for further analysis, regardless of likelihood.

For all areas, the hottest model was CSIRO-Mk3.5. The coolest model differed between areas, as identified in Table 3. By automatically including the hottest model and the four coolest models, the full range of likely temperature change was included for each area. Finally, for the most populated category in each AOGCM area, the model closest to the group median was identified. For four of the areas (WA, SA, NSW and QLD) this was the MRICGCM2.3.2 model. This model was also included for analysis. For the TAS and VIC areas 
many models were equally representative of the group median with no model clearly selectable.

Table 3 Representative area (sites), overall coolest, overall hottest and most likely AOGCMs. The most likely category represents the model closest to group median of most populated category (slightly warmer, warmer or hotter).

\begin{tabular}{l|l|l|l}
\hline Representative area (sites) & Coolest model & Most likely & \multirow{2}{*}{ Hottest model } \\
\hline NSW (Batlow, Orange) & ECHO-G & MRI-CGCM2.3.2 & \\
QLD (Stanthorpe) & ECHO-G & MRI-CGCM2.3.2 & \\
\cline { 1 - 2 } SA (Lenswood) & MIROC3.2_medres & MRI-CGCM2.3.2 & \multirow{2}{*}{ CSIRO Mk 3.5 } \\
\cline { 1 - 2 } TAS (Huonville, Spreyton) & FGOALS-g1.0 & & \\
\cline { 1 - 2 } $\begin{array}{l}\text { VIC (Tatura, Yarra Valley, } \\
\text { Childers) }\end{array}$ & MIROC3.2_medres & & \\
\cline { 1 - 2 } $\begin{array}{l}\text { WA (Manjimup, Donnybrook, } \\
\text { Bakers Hill) }\end{array}$ & BCCR-BCM2.0 & MRI-CGCM2.3.2 & \\
\hline
\end{tabular}

Through this process six models were selected for analysis; CSIRO-Mk3.5, BCCR-BCM2.0, MIROC3.2_medres, FGOALS-g1.0, ECHO-G, MRI-CGCM2.3.2 (Table 3). Suppiah et al. (2007) tested the reliability of 23 AOGCMs in the Australian region and found 15 AOGCMs performed adequately. The six AOGCMs selected here are included in their set of reliable models.

These selected models were also compared to a recent study that partitions 23 AOGCMs based on historical large-scale pattern change of temperature and precipitation (Watterson 2011). Watterson (2011) defined four 'representative future climates' each with particular temperature and precipitation conditions over Australia. The 23 models fell fairly evenly between the four categories resulting in the author concluding each future is equally likely (Watterson 2011). At least one of the six models selected here fell into each of the four categories. Therefore, each of the representative future climates defined by Watterson (2011) have representation in the selection of six AOGCMs, increasing confidence that appropriate uncertainty due to AOGCM variability was included in the results.

\subsection{Projected hourly temperatures}

Expected future warming of the globe will not be uniform, meaning for a global average warming of $1^{\circ} \mathrm{C}$, some regions will warm less and some will warm more than the global average. Seasonal changes are also likely to also vary from the average, with for example summer warming more than winter. Further, minimum and maximum temperatures are also expected to respond differentially to a prescribed degree of warming. These regional and 
temporal variations, as interpreted by AOGCMs, are incorporated into the modelling in this study. As a result, the projections relative to 1,2 and $3^{\circ} \mathrm{C}$ increases in global average temperature are comparable across sites, improving on Hennessy and Clayton-Greene's (1995) initial sensitivity analysis. Methodology also differed from the former sensitivity analysis in that minimum and maximum temperature perturbations were used rather than an average temperature change.

Monthly minimum and maximum temperature perturbations per $1^{\circ} \mathrm{C}$ global temperature increase for each of the six AOGCMs were added to the respective historical daily temperature time-series at each location. For example, the localised August minimum temperature perturbation at Batlow was added to the respective historical August minimum daily temperature time series at Batlow. The temperature perturbations per degree warming were scaled up to represent 2 and $3{ }^{\circ} \mathrm{C}$ global perturbations by simple multiplication of the localised change per degree warming at each site by the respective global temperature increase ( 2 or 3 ). Similarly to $1^{\circ} \mathrm{C}$ perturbations these 2 and $3^{\circ} \mathrm{C}$ changes were added to the historical daily minimum/maximum dataset to produce projected temperature series.

The projected daily temperature time-series were then converted into hourly temperatures, the temporal scale required by the chill models, following the methods in Linvill (1990) and Darbyshire et al. (2011). The hourly temperature projection data were run through each of the three chill models for all six AOGCMs at each location. Chill was defined to accumulate from 1 May - 31 August inclusively for all chill models. Safe winter chill defined by Luedeling et al. (2009c) was calculated and used to investigate changes in chill conditions. The future chill conditions were presented using cumulative probability curves. The 99 years in the historical dataset were used to represent natural variability for 'present' conditions. The perturbed data similarly contained 99 points within each AOGCM to capture likely natural variation. Results using cumulative distribution functions indicate the portion, or percentage, of the distribution that achieves a minimum chill amount. Using safe winter chill, this is the $10^{\text {th }}$ percentile of the data. The intersection of the $10^{\text {th }}$ percentile line with the curves then determined the safe winter chill value. 


\section{Results}

Future chill profiles differed between chill models as demonstrated at Batlow (Figure 2). According to the Dynamic model, a $1{ }^{\circ} \mathrm{C}$ increase in global average temperature caused a small decline in accumulated chill portions, with further warming causing greater decreases. The Modified Utah model results for $1^{\circ} \mathrm{C}$ increase showed little impact on chill accumulation and for some AOGCMs total chill accumulation increased (Figure 2). Again, with further warming, accumulated chill declined. The $0-7.2^{\circ} \mathrm{C}$ model showed a progressive decline in chill accumulation with increases to global average temperatures.

The shape of the distribution of chill received also tended to change according to chill model. At Batlow for the Dynamic model the distribution broadened with warming, meaning the variability of chill received increased. This was particularly evident under the warmest AOGCM for a $3^{\circ} \mathrm{C}$ increase (Figure 2). Limited change was observed in the shape of future chill distribution for the Modified Utah and $0-7.2^{\circ} \mathrm{C}$ model, indicating similar variance to today will continue into the future. 


\section{Batlow}

\section{Dynamic Model}

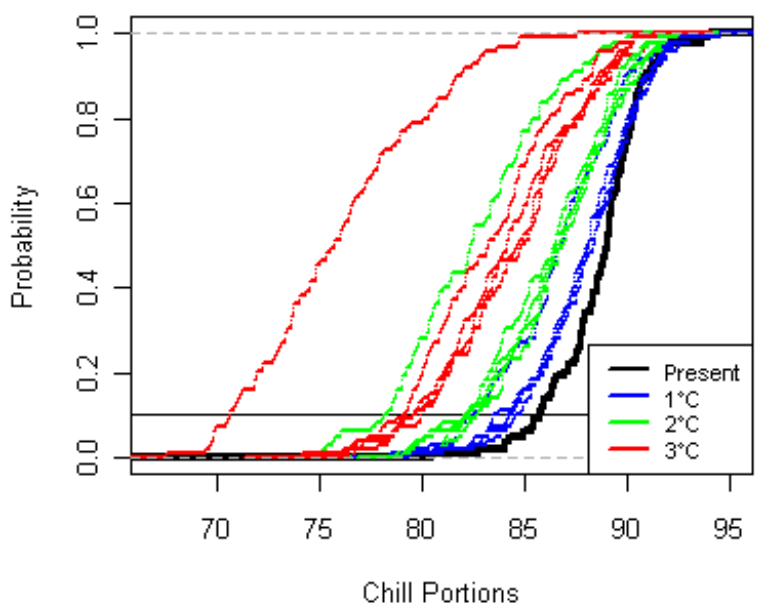

\section{$0-7.2^{\circ} \mathrm{C}$ Model}

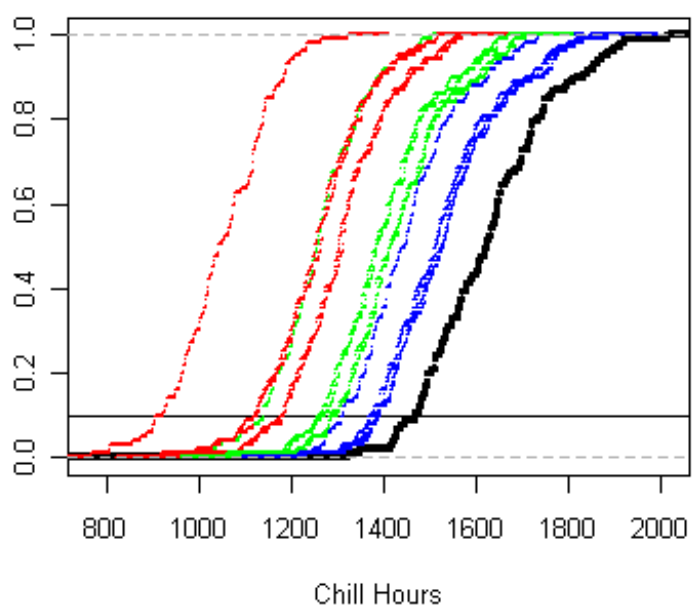

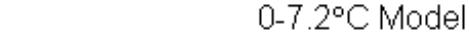

Modified Utah Model

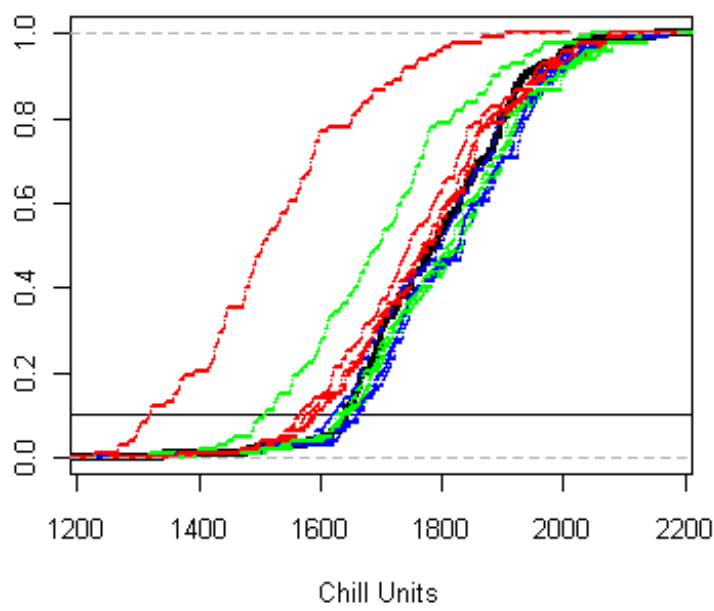

Figure 2 Cumulative distribution functions for projected chill conditions at Batlow (NSW) according to the Dynamic, Modified Utah and $0-7.2^{\circ} \mathrm{C}$ models. Plots indicate current and localised change for 1,2 and $3{ }^{\circ} \mathrm{C}$ global average temperature increase for six AOGCMs. The solid horizontal line is the $10^{\text {th }}$ percentile representing 'safe winter chill'.

Not all locations demonstrated divergence between the chill models. For example, results from Donnybrook indicated a decline across all chill models (Figure 3). Variability did not change greatly with increasing temperature at Donnybrook, except for the $0-7.2^{\circ} \mathrm{C}$ model, which showed less variability with warming. 


\section{Donnybrook}

Dynamic Model
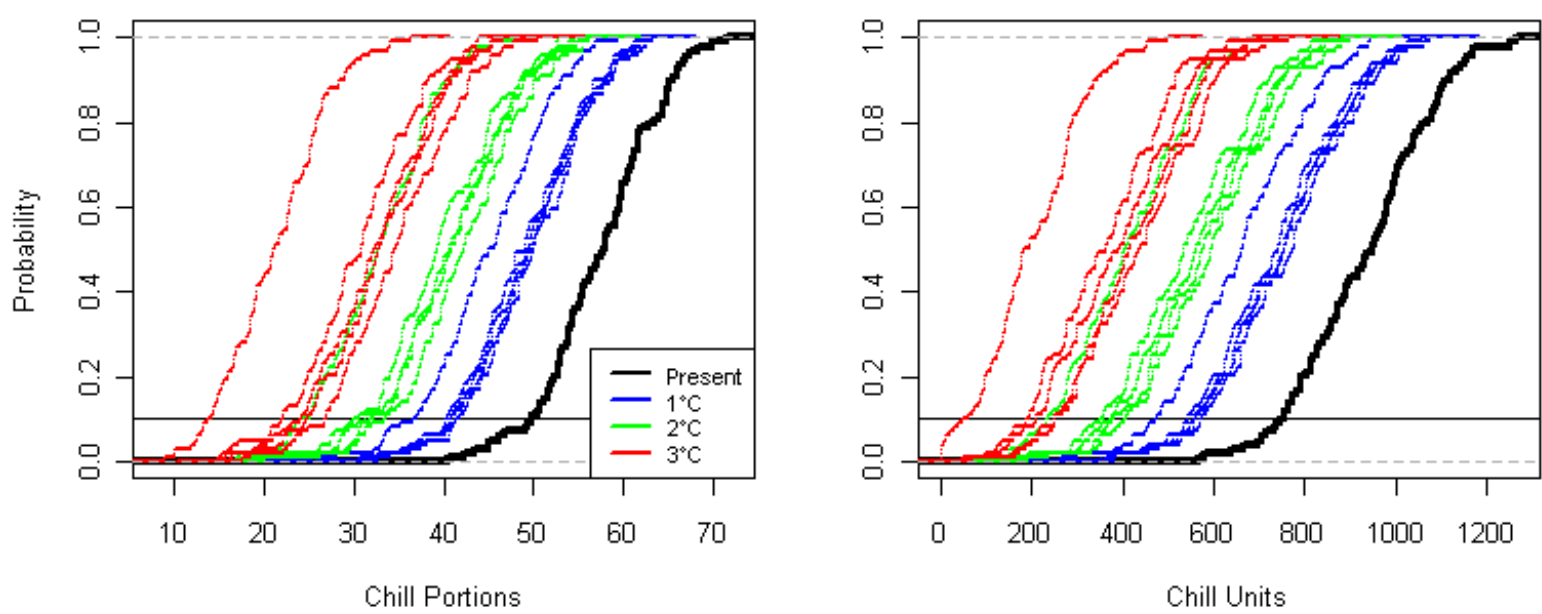

\section{$0-7.2^{\circ} \mathrm{C}$ Model}

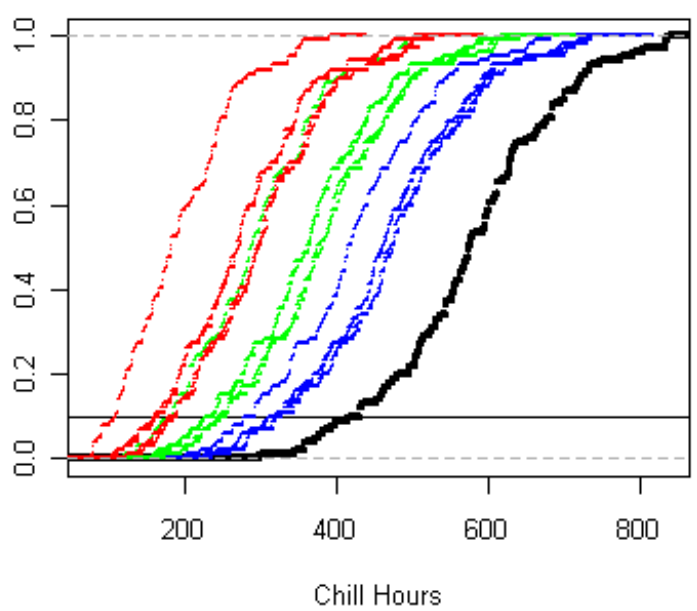

Figure 3 Cumulative distribution functions for projected chill conditions at Donnybrook (WA) according to the Dynamic, Modified Utah and $0-7.2^{\circ} \mathrm{C}$ models. Plots indicate current and localised change for 1,2 and $3^{\circ} \mathrm{C}$ global average temperature increase for six AOGCMs. The solid horizontal line is the $10^{\text {th }}$ percentile representing 'safe winter chill'

Site differences in response to warming were evident (Table 4, Table 5 and Table 6).

Percentage change in safe winter chill from present values was included in the results to indicate likely changes from current conditions. The range of results represents the range of the six AOGCMs.

Table 4 Safe winter chill portions (Dynamic model). The second row contains percentage change in safe winter chill from the historical dataset, that is the 'Present' column. The range in results represents the variation in response resulting from the six AOGCMs selected to represent the range of future temperature projections (Table 3).

\begin{tabular}{l|lrrr}
\hline Location & Present & $1{ }^{\circ} \mathrm{C}$ & $2{ }^{\circ} \mathrm{C}$ & $3^{\circ} \mathrm{C}$ \\
\hline Batlow & 85.7 & $82.6-84.7$ & $78.3-82.7$ & $70.7-79.9$ \\
& - & $-4--1 \%$ & $-9--4 \%$ & $-18--7 \%$
\end{tabular}




\begin{tabular}{|c|c|c|c|c|}
\hline Orange & $\begin{array}{l}80.4 \\
-\end{array}$ & $\begin{array}{r}74.6-78.8 \\
-7--2 \%\end{array}$ & $\begin{array}{r}65.9-74.4 \\
-18--7 \%\end{array}$ & $\begin{array}{l}56.2-71.2 \\
-30--11 \%\end{array}$ \\
\hline Stanthorpe & $\begin{array}{l}66.7 \\
-\end{array}$ & $\begin{array}{r}52.1-60.7 \\
-22--9 \%\end{array}$ & $\begin{array}{r}36.6-53 \\
-45--21 \%\end{array}$ & $\begin{array}{l}22.7-46.1 \\
-66--31 \%\end{array}$ \\
\hline Lenswood & $\begin{array}{l}80.7 \\
-\end{array}$ & $\begin{array}{r}73.9-76.6 \\
-8--5 \%\end{array}$ & $\begin{array}{l}63.6-72.5 \\
-21--10 \%\end{array}$ & $\begin{array}{l}51.2-65.7 \\
-37--19 \%\end{array}$ \\
\hline Huonville & $\begin{array}{l}84.5 \\
-\end{array}$ & $\begin{array}{r}81.6-83 \\
-3--2 \%\end{array}$ & $\begin{array}{r}75.8-8 \\
-10--4 \%\end{array}$ & $\begin{array}{r}68.8-77.2 \\
-19--9 \%\end{array}$ \\
\hline Spreyton & $\begin{array}{l}83.3 \\
-\end{array}$ & $\begin{array}{r}76.4-78.9 \\
-8--5 \%\end{array}$ & $\begin{array}{r}68.3-74 \\
-18--11 \%\end{array}$ & $\begin{array}{l}57.7-67.8 \\
-31--19 \%\end{array}$ \\
\hline Tatura & $\begin{array}{l}74.9 \\
-\end{array}$ & $\begin{array}{r}64.9-68.6 \\
-13--8 \%\end{array}$ & $\begin{array}{l}54.6-64.2 \\
-27--14 \%\end{array}$ & $\begin{array}{r}41-58.3 \\
-45--22 \%\end{array}$ \\
\hline Yarra Valley & $\begin{array}{l}82 \\
-\end{array}$ & $\begin{array}{r}75.2-78.2 \\
-8--5 \%\end{array}$ & $\begin{array}{l}65.2-74.1 \\
-20--10 \%\end{array}$ & $\begin{array}{r}53.7-68 \\
-35--17 \%\end{array}$ \\
\hline Childers & $\begin{array}{l}86.5 \\
-\end{array}$ & $\begin{array}{r}80.1-82.8 \\
-7--4 \%\end{array}$ & $\begin{array}{r}71.6-78.6 \\
-17--9 \%\end{array}$ & $\begin{array}{l}59.1-72.8 \\
-32--16 \%\end{array}$ \\
\hline Bacchus Marsh & $\begin{array}{l}73.6 \\
-\end{array}$ & $\begin{array}{r}65.6-68.9 \\
-11--6 \%\end{array}$ & $\begin{array}{l}52.7-63.1 \\
-28--14 \%\end{array}$ & $\begin{array}{r}39-56 \\
-47--24 \%\end{array}$ \\
\hline Manjimup & $\begin{array}{l}58.8 \\
-\end{array}$ & $\begin{array}{l}45.4-51.7 \\
-23--12 \%\end{array}$ & $\begin{array}{l}32.8-44.6 \\
-44--24 \%\end{array}$ & $\begin{array}{r}21.1-35 \\
-64--40 \%\end{array}$ \\
\hline Donnybrook & $\begin{array}{l}49.7 \\
-\end{array}$ & $\begin{array}{l}36.7-41.6 \\
-26--16 \%\end{array}$ & $\begin{array}{l}24.7-33.3 \\
-50--33 \%\end{array}$ & $\begin{array}{l}13.9-26.7 \\
-72--46 \%\end{array}$ \\
\hline Bakers Hill & $\begin{array}{l}49.8 \\
-\quad \\
\end{array}$ & $\begin{array}{r}35-40.5 \\
-30--19 \%\end{array}$ & $\begin{array}{l}21.8-32.1 \\
-56--36 \%\end{array}$ & $\begin{array}{r}11.4-24 \\
-77--52 \% \\
\end{array}$ \\
\hline
\end{tabular}

Table 5 As for Table 4 but modelled using the Modified Utah model.

\begin{tabular}{l|lrrrr}
\hline Location & Present & $1{ }^{\circ} \mathrm{C}$ & $2^{\circ} \mathrm{C}$ & $3^{\circ} \mathrm{C}$ \\
\hline Batlow & 1641 & $1623-1664$ & $1510-1645$ & $1321-1594$ \\
& - & $-1-1 \%$ & $-8-0 \%$ & $-20--3 \%$ \\
Orange & 1481 & $1378-1455$ & $1198-1404$ & $938-1326$ \\
& - & $-7--2 \%$ & $-19--5 \%$ & $-37--10 \%$ \\
Stanthorpe & 1059 & $795-956$ & $492-838$ & $268-680$ \\
& - & $-25--10 \%$ & $-54--21 \%$ & $-75--36 \%$ \\
\hline Lenswood & 1785 & $1520-1631$ & $1189-1463$ & $842-1256$ \\
& - & $-15--9 \%$ & $-33--18 \%$ & $-53--30 \%$ \\
Huonville & 1737 & $1638-1693$ & $1487-1615$ & $1293-1521$ \\
& - & $-6--3 \%$ & $-14--7 \%$ & $-26--12 \%$ \\
Spreyton & 1734 & $1507-1607$ & $1244-1426$ & $953-1262$ \\
& - & $-13--7 \%$ & $-28--18 \%$ & $-45--27 \%$ \\
\hline Tatura & 1433 & $1184-1306$ & $911-1175$ & $625-1023$ \\
& - & $-17--9 \%$ & $-36--18 \%$ & $-56--29 \%$ \\
\hline Yarra Valley & 1727 & $1508-1614$ & $1219-1462$ & $871-1294$ \\
& - & $-13--7 \%$ & $-29--15 \%$ & $-50--25 \%$ \\
\hline Childers & 1922 & $1696-1804$ & $1395-1640$ & $1041-1451$
\end{tabular}




\begin{tabular}{l|lrrr} 
& - & $-12--6 \%$ & $-27--15 \%$ & $-46--25 \%$ \\
Bacchus Marsh & 1405 & $1141-1262$ & $855-1106$ & $550-935$ \\
& - & $-19--10 \%$ & $-39--21 \%$ & $-61--33 \%$ \\
Manjimup & 1001 & $701-809$ & $389-632$ & $161-440$ \\
\multirow{2}{*}{ Donnybrook } & - & $-30--19 \%$ & $-61--37 \%$ & $-84--56 \%$ \\
& 749 & $472-570$ & $235-406$ & $57-248$ \\
Bakers Hill & - & $-37--24 \%$ & $-69--46 \%$ & $-92--67 \%$ \\
& 801 & $466-613$ & $193-399$ & $7-246$ \\
& - & $-42--23 \%$ & $-76--50 \%$ & $-99--69 \%$ \\
\hline
\end{tabular}

Table 6 As for Table 4 but modelled using the $0-7.2^{\circ} \mathrm{C}$ model.

\begin{tabular}{|c|c|c|c|c|}
\hline Location & Present & $1^{\circ} \mathrm{C}$ & $2^{\circ} \mathrm{C}$ & $3^{\circ} \mathrm{C}$ \\
\hline Batlow & $\begin{array}{l}1466 \\
-\end{array}$ & $\begin{array}{r}1309-1388 \\
-11--5 \%\end{array}$ & $\begin{array}{r}1136-1294 \\
-23--12 \%\end{array}$ & $\begin{array}{l}914-1180 \\
-38--20 \%\end{array}$ \\
\hline Orange & $\begin{array}{l}1263 \\
-\end{array}$ & $\begin{array}{r}1079-1185 \\
-15--6 \%\end{array}$ & $\begin{array}{l}865-1059 \\
-32--16 \%\end{array}$ & $\begin{array}{r}667-934 \\
-47--26 \%\end{array}$ \\
\hline Stanthorpe & $\begin{array}{l}781 \\
-\end{array}$ & $\begin{array}{r}615-692 \\
-21--11 \%\end{array}$ & $\begin{array}{r}447-606 \\
-43--22 \%\end{array}$ & $\begin{array}{r}302-524 \\
-61--33 \%\end{array}$ \\
\hline Lenswood & $\begin{array}{l}681 \\
-\end{array}$ & $\begin{array}{r}438-523 \\
-36--23 \%\end{array}$ & $\begin{array}{r}267-407 \\
-61--40 \%\end{array}$ & $\begin{array}{r}153-292 \\
-78--57 \%\end{array}$ \\
\hline Huonville & $\begin{array}{l}1224 \\
-\end{array}$ & $\begin{array}{r}1048-1106 \\
-14--10 \%\end{array}$ & $\begin{array}{r}861-961 \\
-30--21 \%\end{array}$ & $\begin{array}{r}634-840 \\
-48--31 \%\end{array}$ \\
\hline Spreyton & $\begin{array}{l}873 \\
-\end{array}$ & $\begin{array}{r}669-723 \\
-23--17 \%\end{array}$ & $\begin{array}{r}499-590 \\
-43--32 \%\end{array}$ & $\begin{array}{r}360-466 \\
-59--47 \%\end{array}$ \\
\hline Tatura & $\begin{array}{l}941 \\
-\end{array}$ & $\begin{array}{r}735-815 \\
-22--13 \%\end{array}$ & $\begin{array}{r}542-693 \\
-42--26 \%\end{array}$ & $\begin{array}{r}375-562 \\
-60--40 \%\end{array}$ \\
\hline Yarra Valley & $\begin{array}{l}1020 \\
-\end{array}$ & $\begin{array}{r}777-863 \\
-24--15 \%\end{array}$ & $\begin{array}{r}539-716 \\
-47--30 \%\end{array}$ & $\begin{array}{r}342-572 \\
-66--44 \%\end{array}$ \\
\hline Childers & $\begin{array}{l}995 \\
-\end{array}$ & $\begin{array}{r}698-809 \\
-30--19 \%\end{array}$ & $\begin{array}{r}469-636 \\
-53--36 \%\end{array}$ & $\begin{array}{r}288-495 \\
-71--50 \%\end{array}$ \\
\hline Bacchus Marsh & $\begin{array}{l}865 \\
-\end{array}$ & $\begin{array}{r}647-726 \\
-25--16 \%\end{array}$ & $\begin{array}{r}452-602 \\
-48--30 \%\end{array}$ & $\begin{array}{r}302-485 \\
-65--44 \%\end{array}$ \\
\hline Manjimup & $\begin{array}{l}325 \\
-\end{array}$ & $\begin{array}{r}192-232 \\
-41--29 \%\end{array}$ & $\begin{array}{r}108-165 \\
-67--49 \%\end{array}$ & $\begin{array}{r}52-114 \\
-84--65 \%\end{array}$ \\
\hline Donnybrook & $\begin{array}{l}427 \\
-\end{array}$ & $\begin{array}{r}288-326 \\
-33--24 \%\end{array}$ & $\begin{array}{r}182-251 \\
-57--41 \%\end{array}$ & $\begin{array}{r}107-186 \\
-75--56 \%\end{array}$ \\
\hline Bakers Hill & $\begin{array}{l}364 \\
-\end{array}$ & $\begin{array}{r}221-281 \\
-39--23 \%\end{array}$ & $\begin{array}{r}119-203 \\
-67--44 \%\end{array}$ & $\begin{array}{r}59-142 \\
-84--61 \%\end{array}$ \\
\hline
\end{tabular}

Changes to safe winter chill differed between the chill models. For instance, $3^{\circ} \mathrm{C}$ warming at Lenswood using the Dynamic model indicated a $19-37 \%$ decline in safe winter chill compared to current conditions while the Modified Utah model suggested a 30 - 53\% drop and the $0-7.2^{\circ} \mathrm{C}$ model was more severe with a $57-78 \%$ reduction. The three Western 
Australia sites (Manjimup, Donnybrook and Bakers Hill) recorded the greatest decline in safe winter chill across all chill models. Other sites showed a much lower impact, particularly Batlow, Orange and Huonville. In general, the Dynamic model showed the least decline in safe winter chill, followed by the Modified Utah model while the $0-7.2^{\circ} \mathrm{C}$ model tended to predict slightly larger reductions.

\section{Discussion}

The results from this study update and expand the only other chilling projection assessment for Australia (Hennessy and Clayton-Greene 1995) and contributes to the small number of studies that have calculated chill projections across the globe (Baldocchi and Wong 2008; Luedeling et al. 2011; Luedeling et al. 2009a). Findings broadly support Luedeling et al. (2011) global analysis of chill using the Dynamic model, indicating a decline in chill with increasing temperature over Australia. Site sensitivity to warming showed locations that are currently cooler (e.g. Batlow, Huonville and Orange) will experience a minor impact while warmer sites (e.g. Bakers Hill, Manjimup and Donnybrook) will be more adversely affected.

Comparison of results to Hennessy and Clayton-Greene's (1995) assessment of future chilling conditions in Australia showed general agreement. Six locations were common to both studies with the values in Hennessy and Clayton-Greene (1995) mostly falling within the ranges reported here. A notable exception was Orange; 1908 chill units were computed for Orange under $3^{\circ} \mathrm{C}$ warming according to Hennessy and Clayton-Greene (1995), which is more than current conditions according to this assessment (1481 chill units). This discrepancy has several potential causes. Firstly, different baseline climate datasets were used. Hennessy and Clayton-Greene (1995) used historical observations from stations with two or more years of continuous daily data while historical temperature surfaces spanning 99 years (Jones et al. 2009) were used here. Different projection data were also used. Here, localised monthly maximum and minimum warming according to mean global temperature increases was used whilst Hennessy and Clayton-Greene (1995) used simple 1, 2 and $3{ }^{\circ} \mathrm{C}$ additions for their sensitivity study. Secondly, different chill periods were applied. The chill period was bounded in this study while Hennessy and Clayton-Greene (1995) used the inbuilt model definition (the positive part of the curve). Finally, safe winter chill was used for analysis here while Hennessy and Clayton-Greene (1995) used mean accumulation, which will produce higher values. 
The projected results can be used to evaluate appropriate growing regions into the future, assisting with forward planning and adaptation strategies. For instance, Zhang and Taylor (2011) determined a chill threshold of 59 chill portions for Sirora pistachio (Table 1). An industry report discussed expansion of pistachios in Australia (Robinson 1998) and identified locations near Tatura, Orange and Batlow, among other sites, as potential areas for development. According to the results found here, sufficient chill will be accumulated at Batlow under all warming scenarios for this variety. Orange is also likely to be suitable in regard to chill conditions, however one AOGCM indicates insufficient chill with $3^{\circ} \mathrm{C}$ warming. Tatura is likely to become unsuitable for Sirora pistachio with $2^{\circ} \mathrm{C}$ or more increases to global average temperatures. It should be appreciated that chill is only one climate aspect that needs consideration for industry expansion with other conditions, such as rainfall, also important to incorporate.

Given these results, adaptation of current planting can be considered in the context of likely exposure to adequate chill. Locations at risk of receiving insufficient chill have several management options available. For instance, rest breaking agents can be applied to existing crops in areas where insufficient chill is expected (e.g. Petri et al. 2008; Sheard et al. 2009). When replanting, growers may consider planting lower chill varieties (e.g. Topp and Sherman 2000). For some locations, larger transformational change may be necessary such as converting to different horticultural crops or production systems. These decisions will be dependent on many factors, including trends in other climate variables as well as market and social drivers. Given the various adaptation options (Webb and Whetton 2010), regional effects and different grower capacity (Marshall et al. 2010) sweeping change is unlikely to occur and adaptation will differ from farm-to-farm.

In order for the fruit and nut industry to use the results found here, further on site research on varietal chill thresholds is required. Many cultivars have not been the subject of chill analysis (e.g. Pink Lady apple) and certainly not within Australia. This is particularly important as recent research has indicated that geographical location may substantially affect required chilling (Campoy et al. 2012). Although different chill models have been used in chill analyses, there is growing support and evidence to suggest that they are not equally accurate in capturing the chilling process. It is recommended new analyses or field observations be carried out using the Dynamic model due to positive findings in the literature (Alburquerque 
et al. 2008; Campoy et al. 2011a; Erez et al. 1990; Luedeling et al. 2009b; Perez et al. 2008; Ruiz et al. 2007; Viti et al. 2010) and the appealing structure leading it to be described as the current milestone dormancy model (Campoy et al. 2011b). Use of other chill models for planning purposes may cause mismanagement as these models do not capture the chilling process as well as the Dynamic model.

Variability in chill received, also important for management, differed between the models. Changes in variability are reflected by changes to the slope of the cumulative probability curves. A steeper curve indicates less variability while a flatter curve relates to greater variability. The $0-7.2^{\circ} \mathrm{C}$ model indicated similar or a decrease in variability with increased global average temperature. The observed decrease in variability was more prevalent in warmer locations (e.g. Donnybrook, Figure 3). This is likely to be a result of the chill model structure which has sharp step-change boundaries. For example, at Donnybrook a larger proportion of temperatures fell higher than the $7.2^{\circ} \mathrm{C}$ boundary, lowering the overall accumulated chill and shrinking the right tail of the distribution, lowering the overall variability.

The Modified Utah model was the only model to record an increase in chill with warming (Batlow). The model structure is the underlying cause. Batlow is a cold location by Australian standards with a mean winter temperature of approximately $3.8-6.2^{\circ} \mathrm{C}$ (Table 2 ). An increase of $1^{\circ} \mathrm{C}$ to global average temperature moved temperatures at Batlow into the optimum temperature range of the Modified Utah model, which peaks at $7^{\circ} \mathrm{C}$. Therefore total chill accumulation slightly increased for some of the AOGCMs, however further warming pushed temperatures passed this optimum, causing a decline in chill accumulation.

Generally, the Dynamic model recorded lower percentage loss of safe winter chill across all locations. The dampening effect observed is likely a result of complexity of the relationship between temperature and chill in the model. The negation of high temperatures in the Dynamic model is quite intricate, dependent on the temperature value, duration and interaction with low temperatures. Additionally, the Dynamic model has provisions for enhancing chill accumulation when chilling temperatures are cycled with moderate temperatures $\left(13-15^{\circ} \mathrm{C}\right)$. The sophistication of the Dynamic model makes diagnosis of causation of observed changes more difficult. 
Fixed chill periods were used in this assessment to calculate future chilling conditions. It is possible that timing of both the initiation and breaking of dormancy could shift with a changing climate. Depending on how the chill period is modified, artificial addition of warmer temperatures may have been included in this assessment, slightly over-estimating declines. However, as Luedeling et al. (2011) comment the Dynamic model has an inbuilt process which restricts chill accumulation to periods of appropriate chilling temperatures. Therefore any bias would be mostly characterised in results from the Modified Utah model, due to time independent negation of higher temperatures.

The timing of future impacts due to enhanced greenhouse conditions are dependent on how GHG emission pathways evolve. This study specifically avoided framing the analysis using GHG emission scenarios (Nakicenovic and Swart 2000) to ensure results remain relevant if SRES pathways become redundant. However, an indication of likely timing of the impacts can be provided assuming a SRES framework does eventuate. For instance, a $1^{\circ} \mathrm{C}$ increase to global average temperatures is expected to occur around 2030 according to high emission scenarios (IPCC 2007), while this may be delayed if a lower emissions pathway is followed. Similarly, $2^{\circ} \mathrm{C}$ increase is expected to occur at about 2050 for a fossil fuel intensive pathway (IPCC 2007) though may not occur until the next century if aggressive global mitigation efforts are enacted. Increases to global average temperature of $3^{\circ} \mathrm{C}$ are expected to occur around 2070 at the earliest, again timing is dependent on emission scenario, or more specifically, on global emissions and mitigation efforts. The advantage of using the emission scenarios to inform likely timeframes of impacts rather than have them define the impacts themselves is that if emission storylines are modified, reassessment of the time that threshold global temperatures are reached is required rather than reanalysis of the entire impact study.

AOGCMs are constantly developed alongside GHG emission scenarios. Reanalysis of impact assessments may be necessary if results from updated AOGCMs are significantly different from the models used in this study. Nonetheless, AOGCM selection is very important in climate change impact analyses as results can vary greatly between models (Jun et al. 2008; Watterson 2011). Inclusion of a justification of AOGCM selection is a point of difference in this analysis compared to other impact studies (Baldocchi and Wong 2008; Eccel et al. 2009; Kaukoranta et al. 2010; Luedeling et al. 2011; Luedeling et al. 2009c). The approach to subselect AOGCMs used was relatively simple but the full range of results from the available models are likely to have been captured and the selection was cross-checked with studies of 
climate model skill to avoid accidental bias. While more scrutiny of the reliability of individual AOGCMs could have been carried out, the aim of this study was to assess changes in chill rather than complete a model skill analysis. Through using previous climate model performance studies, a justification of the inclusion of AOGCMs was described. Such defences for model selection are recommended in all climate change impact studies.

\section{Conclusions}

This analysis represents a significant update to the previous climate impact analysis of chill in Australia and highlights that sensitivity studies are a useful method for impact assessments. Regional differences of impacts on chill are likely in Australia, with the Western Australia sites most adversely affected, potentially impacting future production success. The severity and rate of decline in chill accumulation was dependent on which chill model was used with the Dynamic model indicating a slower rate of decline followed by the Modified Utah and 0$7.2^{\circ} \mathrm{C}$ models.

Many varietal thresholds have been reported in different, non-convertible, units. However, use of the results found here in combination with thresholds determined using the $0-7.2^{\circ} \mathrm{C}$ or Modified Utah models is not recommended. As the Dynamic model has been shown to be the most plausible descriptor of chill it should be used for future chill threshold assessments and management decisions. Indeed, reassessment of chill requirements using the Dynamic model is also required. Use of alternate chill models may lead to mismanagement as they do not characterise chill as well as the Dynamic model.

Projections using a sensitivity approach of localised temperature change per global average temperature increase simplified the communication of future climate projection uncertainty and the results will remain viable into the future, and regardless of GHG emission pathways. AOGCM selection was highlighted as an important methodological factor for consideration, with the use of climate model performance assessments and justification of included models key aspects that should be included in all impact assessments. Future farm management decisions can be made with consideration of the likely changes in chill accumulation reported here, with adaptation, at least to some degree, being necessary for most production areas in Australia within the next 50 years. 


\section{Acknowledgements}

The authors thank the Australian Bureau of Meteorology for providing the historical data and QCCCE and CSIRO for the projection data used in the analysis. Ian Smith (BOM), Kevin Hennessy (CSIRO) and Jim Ricketts (QCCCE) also provided valuable advice on data and methodology.

\section{References}

-Montiel F, Carrillo A, Burgos L (2008) Chilling and heat requirements of sweet cherry cultivars and the relationship between altitude and the probability of satisfying the chill requirements. Environ Exp Bot 64 (2):162-170

Alonso JM, Anson JM, Espiau MT, Company RSI (2005) Determination of endodormancy break in almond flower buds by a correlation model using the average temperature of different day intervals and its application to the estimation of chill and heat requirements and blooming date. J Am Soc Hortic Sci 130 (3):308-318

Ashcroft GL, Richardson EA, Seeley SD (1977) Statistical-method of determining chill unit and growing degree hour requirements for deciduous fruit-trees. HortScience 12 (4):347-348

Baldocchi D, Wong S (2008) Accumulated winter chill is decreasing in the fruit growing regions of California. Climatic Change 87:S153-S166

Bennett JP (1949) Temperature and bud rest period. Califor Agric 3 (11):12

Campoy JA, Ruiz D, Allderman L, Cook N, Egea J (2012) The fulfilment of chilling requirements and the adaptation of apricot (Prunus armeniaca L.) in warm winter climates: An approach in Murcia (Spain) and the Western Cape (South Africa). Eur J Agron 37 (1):43-55

Campoy JA, Ruiz D, Cook N, Allderman L, Egea J (2011a) Clinal variation of dormancy progression in apricot. S Afr J Bot 77 (3):618-630

Campoy JA, Ruiz D, Egea J (2011b) Dormancy in temperate fruit trees in a global warming context: A review. Sci Hortic-Amsterdam 130 (2):357-372

Cesaraccio C, Spano D, Snyder RL, Duce P (2004) Chilling and forcing model to predict bud-burst of crop and forest species. Agr Forest Meteorol 126 (1-2):1-13

Clarke JM, Whetton PH, Hennessy KJ Providing Application-specific Climate Projections Datasets: CSIRO's Climate Futures Framework. In: Chan F, Marinova D, Anderssen RS (eds) MODSIM2011, 19th International Congress on Modelling and Simulation. Modelling and Simulation Society of Australia and New Zealand, Perth, Australia, 12-16 December 2011. pp 2683-2690

Darbyshire R, Webb L, Goodwin I, Barlow S (2011) Winter chilling trends for deciduous fruit trees in Australia. Agr Forest Meteorol 151:1074-1085

Dennis FG (1994) Dormancy - What we know (and don't know). HortScience 29 (11):12491255

Eccel E, Rea R, Caffarra A, Crisci A (2009) Risk of spring frost to apple production under future climate scenarios: the role of phenological acclimation. Int J Biometeorol 53:273-286

Erez A, Fishman S, Linsley-Noakes GC, Allan P (1990) The dynamic model for rest completion in peach buds. Acta Hortic 279:165-174 
Fishman S, Erez A, Couvillon GA (1987) The temperature-dependence of dormancy breaking in plants - Computer-simulation of processes studied under controlled temperatures. J Theor Biol 126 (3):309-321

Ghariani K, Stebbins RL (1994) Chilling requirements of apple and pear cultivars. Fruit Varieties J 48 (4):215-222

Harrington CA, Gould PJ, St.Clair JB (2010) Modeling the effects of winter environment on dormancy release of Douglas-fir. Forest Ecol Manag 259 (4):798-808

Hennessy K, Clayton-Greene K (1995) Greenhouse warming and vernalisation of high-chill fruit in southern Australia. Climatic Change 30:327-348

IPCC (2007) Climate Change 2007: The physical science basis - contribution of working group I to the fourth assessment report of the Intergovernmental Panel on Climate Change. Cambridge University, Cambridge

Jones D, Wang W, Fawcett R (2009) High-quality spatial climate data-sets for Australia. Aust Meteoro Oceanogr J 58:233-248

Jun M, Knutti R, Nychka DW (2008) Spatial Analysis to Quantify Numerical Model Bias and Dependence: How Many Climate Models Are There? J Am Stat Assoc 103 (483):934947. doi:10.1198/016214507000001265

Kaukoranta T, Tahvonen R, Ylamaki A (2010) Climatic potential and risks for apple growing by 2040. Agr Food Sci Finland 19 (2):144-159

Legave J, Farrera I, Almeras T, Calleja M (2008) Selecting models of apple flowering time and understanding how global warming has had an impact on this trait. J Hortic Sci Biotech 83 (1):76-84

Linsley-Noakes GC, Allan P, Matthee G (1994) Modification of rest completion prediction models for improved accuracy in South African stone fruit orchards. J South Afr Soc Hortic Sci 4 (1):13-15

Linvill DE (1990) Calculating chilling hours and chill units from daily maximum and minimum temperature observations. HortScience 25 (1):14-16

Luedeling E, Brown P (2010) A global analysis of the comparability of winter chill models for fruit and nut trees. Int J Biometeorol 55 (3):411-421.

Luedeling E, Girvetz EH, Semenov MA, Brown PH (2011a) Climate change affects winter chill for temperate fruit and nut trees. PLoS One 6 (5)

Luedeling E, Kunz A, Blanke M (2011b). Mehr Chilling für Obstbäume in wärmeren Wintern? (More winter chill for fruit trees in warmer winters?). Erwerbs-Obstbau 53:145-155

Luedeling E, Zhang M, Luedeling V, Girvetz E (2009a) Sensitivity of winter chill models for fruit and nut trees to climate changes expected in California's central valley. Agric Ecosyst Environ 133:23-31

Luedeling E, Zhang M, McGranahan G, Leslie C (2009b) Validation of winter chill models using historic records of walnut phenology. Agric Forest Meteorol 149:1854-1864

Luedeling E, Zhang MH, Girvetz EH (2009c) Climatic Changes Lead to Declining Winter Chill for Fruit and Nut Trees in California during 1950-2099. PLoS One. doi:e6166 10.1371/journal.pone.0006166

Luedeling E, Blanke M, Gebauer J (2009d). Auswirkungen des Klimawandels auf die Verfügbarkeit von Kältewirkung (Chilling) für Obstgehölze in Deutschland (Climate change effects on winter chill for fruit crops in Germany). Erwerbs-Obstbau 51:81-94

Mankotia MS, Chauhan PS, Sud A (2004) Estimation of effective chilling hours and GDH degree $\mathrm{C}$ requirement and its significance in predicting full bloom in delicious apple. In: Jindal KK, Sharma RC, Rehalia AS (eds) Proceedings of the Viith International Symposium on Temperate Zone Fruits in the Tropics and Subtropics. Acta Hortic 662: 83-86 
Marshall NA, Stokes CJ, Howden SM, Nelson RN (2010) Enhancing adaptive capacity. In: Howden M, Stokes C (eds) Adapting agriculture to climate change: preparing Australian agriculture, foresty and fisheries for the future. CSIRO Publishing, Melbourne

Meinshausen M, Meinshausen N, Hare W, Raper SCB, Frieler K, Knutti R, Frame DJ, Allen MR (2009) Greenhouse-gas emission targets for limiting global warming to 2 degrees C. Nature 458 (7242):1158-1196.

Nakicenovic N, Swart R (eds) (2000) IPCC Special Report on Emission Scenarios. Cambridge

Oukabli A, Bartolin S, Viti R (2003) Anatomical and morphological study of apple (Malus X domestica Borkh.) flower buds growing under inadequate winter chilling. J Hortic Sci Biotech 78 (4):580-585

Page CM, Jones D OzClim: The development of a climate scenario generator for Australia. In: Zerger A, Argent RM (eds) MODSIM 2001 International Congress on Modelling and Simulation, Modelling and Simulation Society of Australia and New Zealand, 2001.

Perez FJ, Ormeno JN, Reynaert B, Rubio S (2008) Use of the dynamic model for the assessment of winter chilling in a temperature and a subtropical climatic zone of Chile. Chil J Agr Res 68:198-206

Petri JL, Berenhauser Leite G, Putti GL (2008) Apple tree budbreak promoters in mild winter conditions. In: Webster AD, Palta J, Lee Y, Lee JM (eds) Proceedings of the International Symposium on Endogenous and Exogenous Plant Bioregulators. Acta Hortic 774:291-295

Petri JL, Leite GB (2004) Consequences of insufficient winter chilling on apple tree budbreak. In: Jindal KK, Sharma RC, Rehalia AS (eds) Proceedings of the Viith International Symposium on Temperate Zone Fruits in the Tropics and Subtropics. Acta Hortic 662: 53-60

Ramírez L, Sagredo KX, Reginato GH (2010) Prediction models for chilling and heat requirements to estimate full bloom of almond cultivars in the Central Valley of Chile. Acta Hortic 872:107-112

Richardson EA, Seeley SD, Walker DR (1974) A model for estimating the completion of rest for redhaven and elberta peach trees. HortScience 9 (4):331-332

Ricketts JH, Page CM (2007) A Web Based Version of OzClim for Exploring Climate Change Impacts and Risks in the Australian Region. Modsim 2007: International Congress on Modelling and Simulation - Land, Water and Environmental Management: Integrated Systems for Sustainability. Univ Western Australia, Nedlands

Robinson B (1998) Pistachios. In: Hyde KW (ed) The New Rural Industries: A Handbook for Farmers and Investors. Rural Industries Research \& Development Corporation

Ruiz D, Campoy J, Egea J (2007) Chilling and heat requirements of apricot cultivars for flowering. Environ Exp Bot 61:254-263

Saure MC (1985) Dormancy release in deciduous fruit trees. Hortic Rev 7:239-300

Schwartz MD, Hanes JM (2010) Continental-scale phenology: warming and chilling. Int J Climatol 30:1959-1598

Shaltout AD, Unrath CR (1983) Rest completion prediction model for Starkrimson Delicious apples. J Am Soc Hortic Sci 108 (6):957-961

Sheard AG, Johnson SD, Cook NC (2009) Effect of timing and concentration of rest breaking agents on budburst in 'Bing' sweet cherry under conditions of inadequate winter chilling in South Africa. S Afr J Plant \& Soil 26 (2):73-79 
Smith I, Chandler E (2010) Refining rainfall projections for the Murray Darling Basin of south-east Australia - the effect of sampling model results based on performance. Climatic Change 102:377-393

Sunley RJ, Atkinson CJ, Jones HG (2006) Chill unit models and recent changes in the occurrence of winter chill and spring frost in the United Kingdom. J Hortic Sci Biotech 81 (6):949-958

Suppiah R, Hennessy K, Whetton PH, McInnes K, Macadam I, Bathols J, Ricketts J, Page CM (2007) Australian climate change projections derived from simulations performed for the IPCC 4th Assessment Report. Aust Meteorol Mag 56 (3):131-152

Topp BL, Sherman WB (2000) Breeding strategies for developing temperature fruits for the sub-tropics, with particular reference to Prunus. Acta Hortic 522:235-240

van Oldenborgh GJ, Philip SY, Collins M (2005) El Nino in a changing climate: a multimodel study. Ocean Sci 1:81-95

Viti R, Andreini L, Ruiz D, Egea J, Bartolini S, Iacona C, Campoy JA (2010) Effect of climatic conditions on the overcoming of dormancy in apricot flower buds in two Mediterranean areas: Murcia (Spain) and Tuscany (Italy). Sci Hortic-Amsterdam 124 (2):217-224. doi:10.1016/j.scienta.2010.01.001

Voller CFP (1986) Predicting rest-breaking: Principles and problems. Decid Fruit Grow 36 (8):302-308

Wand SJE, Steyn WJ, Theron KI (2008) Vulnerability and impact of climate change on pear production in South Africa. In: Webster ADOCM (ed) Proceedings of the Xth International Pear Symposium, Vols 1 and 2. Acta Hortic 800:263-271

Watterson IG (2011) Understanding and partitioning future climates for Australian regions from CMIP3 using ocean warming indices. Climatic Change. doi:10.1007/s10584011-0166-X

Webb L, Whetton PH (2010) Horticulture. In: Howden M, Stokes C (eds) Adapting agriculture to climate change: Preparing Australian agiculture, foresty and fisheries for the future. CSIRO Publishing, Melbourne,

Weinberger JH (1950) Chilling requirements of peach varieties. Proceedings of the American Society for Horticultural Science 56 (Dec): 122-128

Zhang J, Taylor C (2011) The Dynamic model provides the best description of the chill process on 'Sirora' pistachio trees in Australia. HortScience 46 (3):420-425 


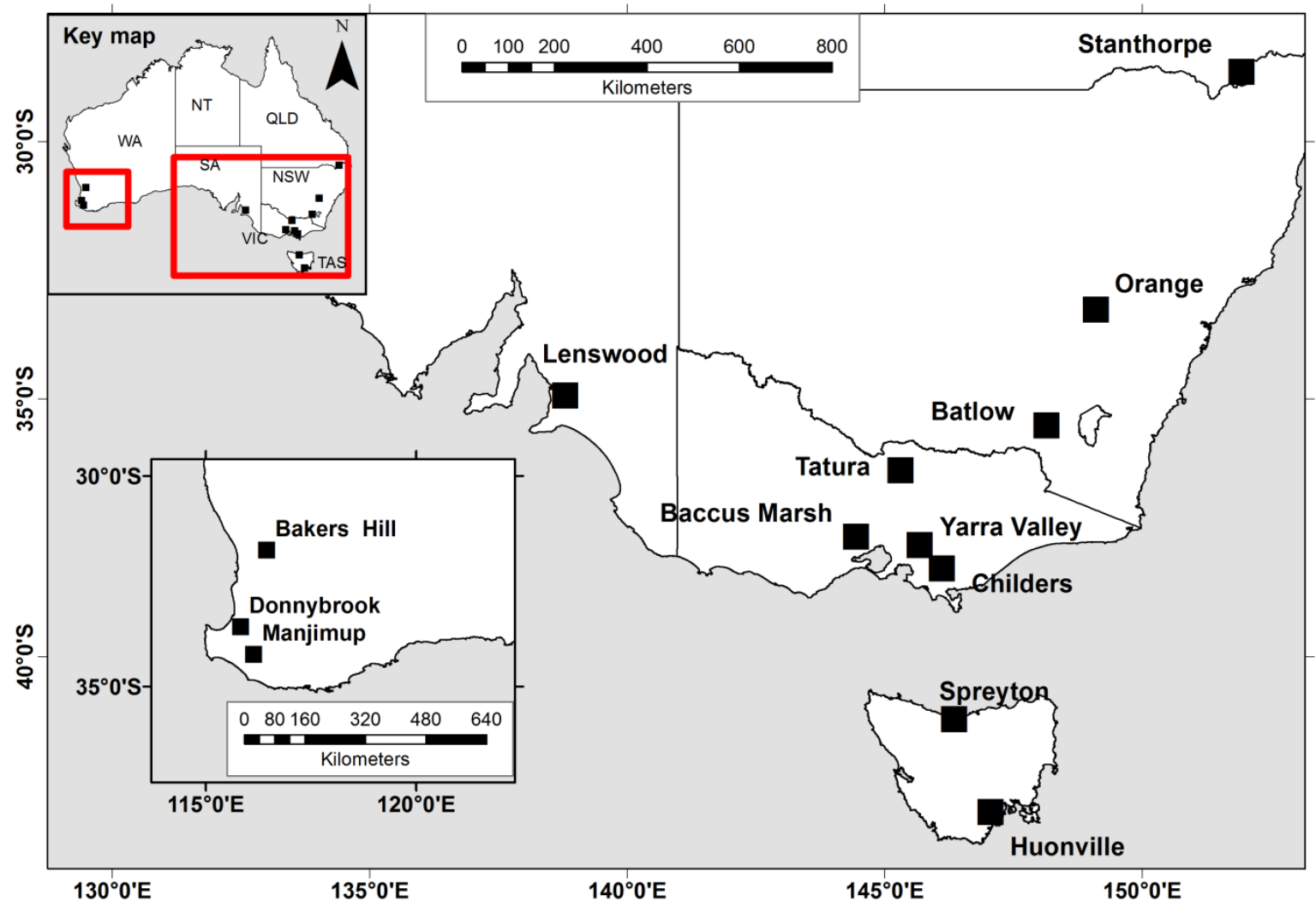


Batlow

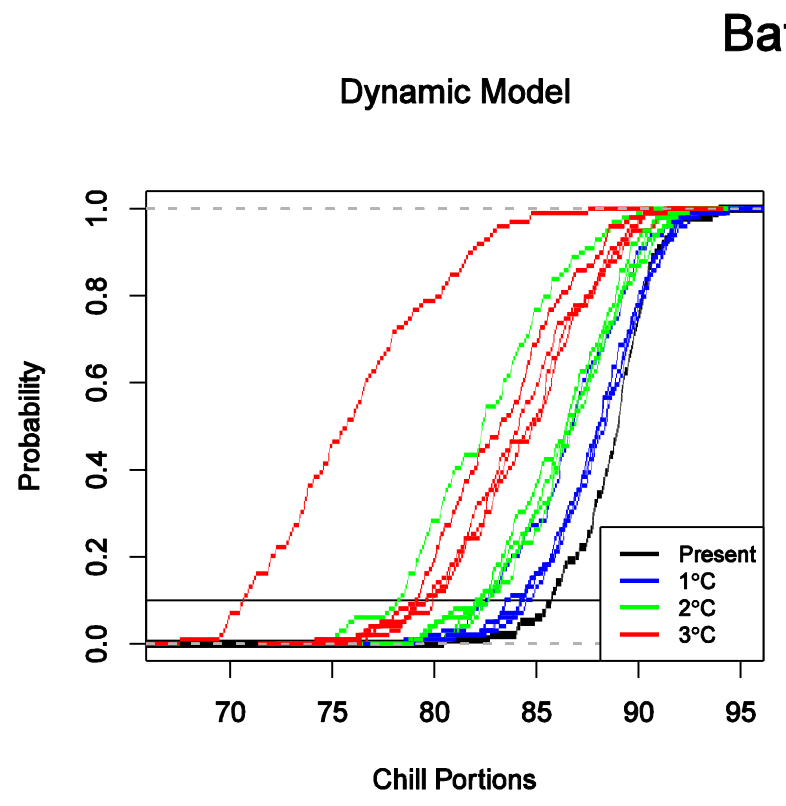

Dynamic Model

0-7.2 ${ }^{\circ} \mathrm{C}$ Model

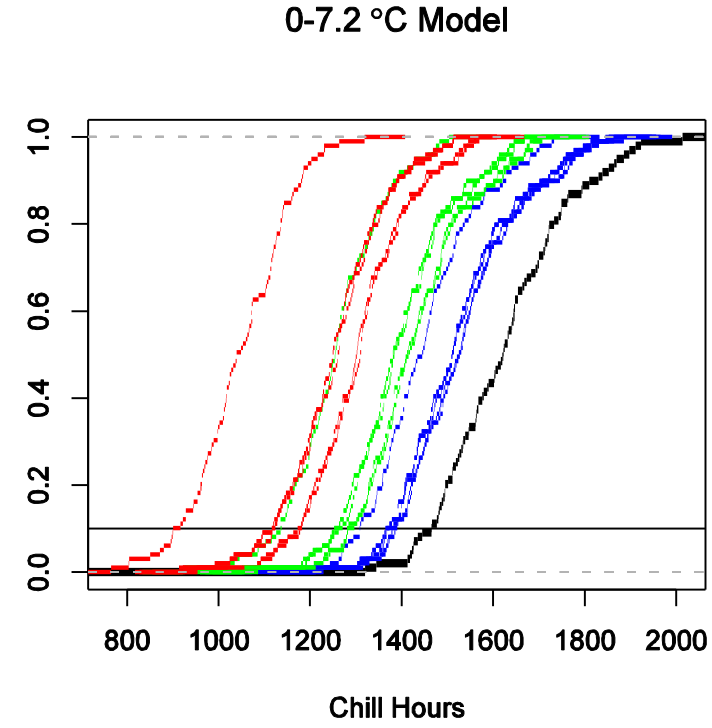

Modified Utah Model

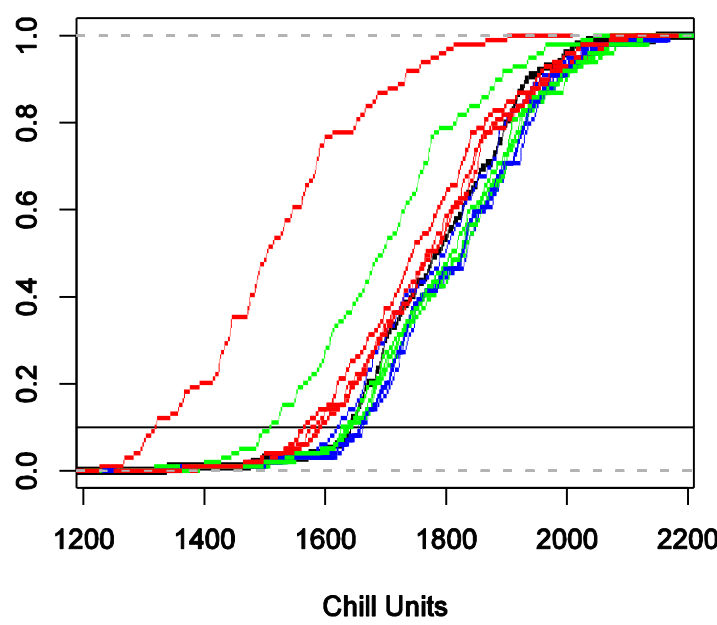




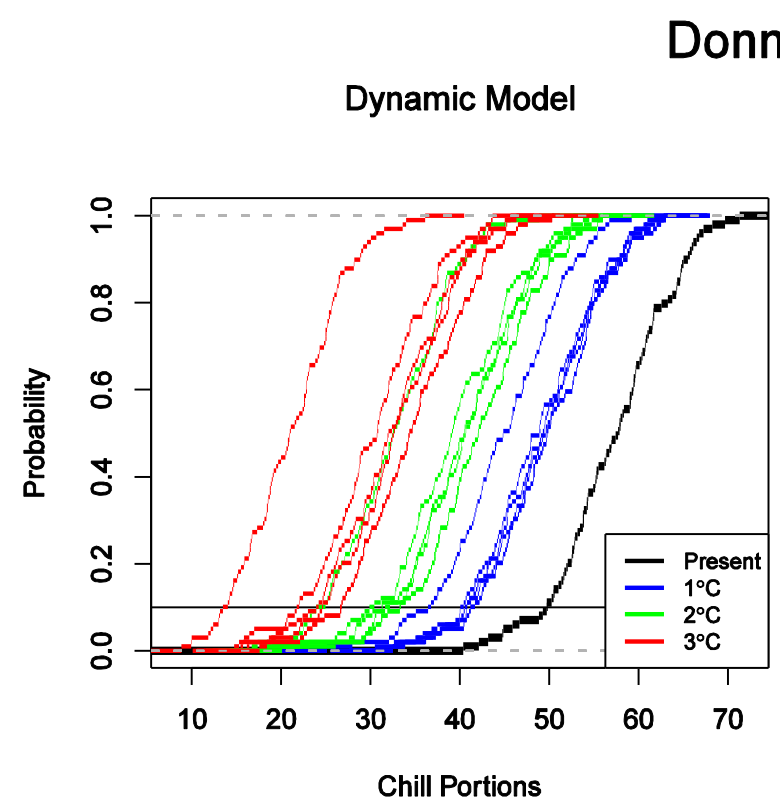

Modified Utah Model

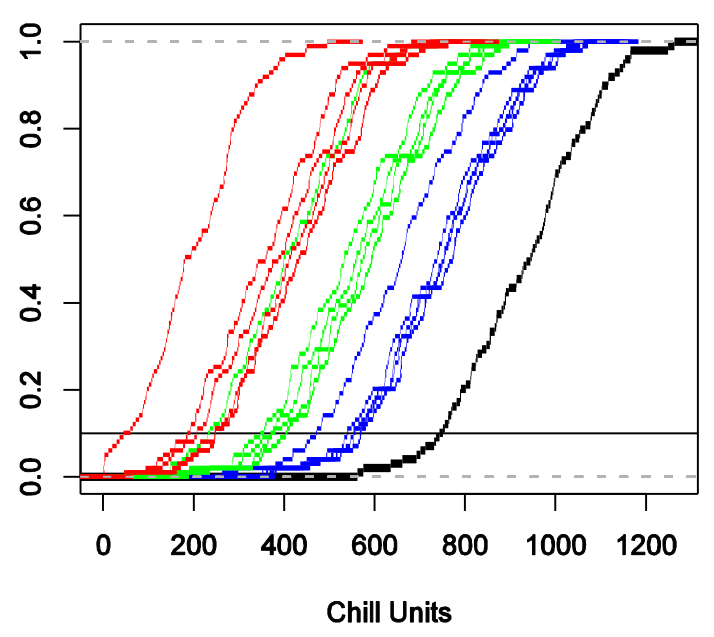

0-7.2 ${ }^{\circ} \mathrm{C}$ Model

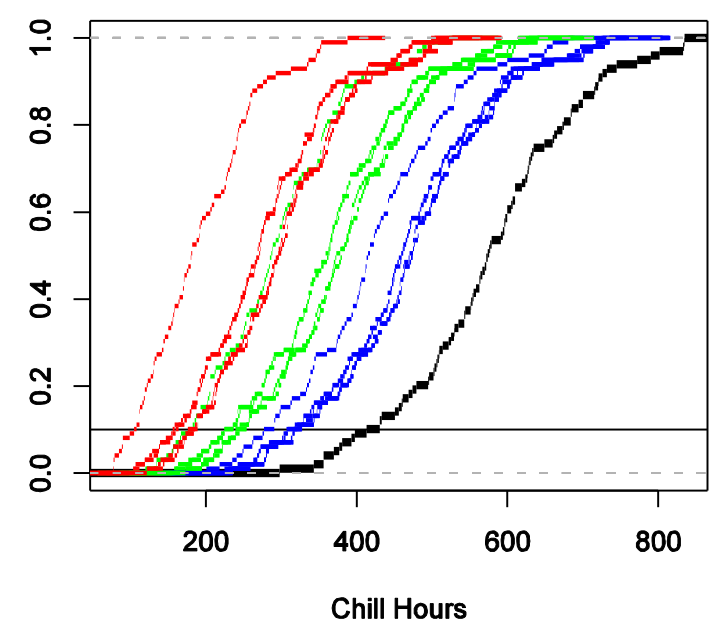




\section{University Library}

\section{- M M N E R VA A gateway to Melbourne's research publications}

Minerva Access is the Institutional Repository of The University of Melbourne

Author/s:

Darbyshire, R;Webb, L;Goodwin, I;Barlow, EWR

Title:

Impact of future warming on winter chilling in Australia

Date:

2013-05-01

Citation:

Darbyshire, R., Webb, L., Goodwin, I. \& Barlow, E. W. R. (2013). Impact of future warming on winter chilling in Australia. INTERNATIONAL JOURNAL OF BIOMETEOROLOGY, 57 (3), pp.355-366. https://doi.org/10.1007/s00484-012-0558-2.

Persistent Link:

http://hdl.handle.net/11343/282982 